\title{
3,3'-di-O-methylellagic acid, an Antioxidant Phenolics Compound from Sonneratia alba Bark
}

\author{
Netti Herawati ${ }^{1 *}$ and Firdaus ${ }^{2)}$ \\ ${ }^{1)}$ Departement Chemistry of Makassar State University 90222 \\ ${ }^{2}$ Departement Chemistry of Hasanuddin University 90245 \\ Received 27-02-2012 Approved 27-02-2013
}

\begin{abstract}
Free radicals play an important role in some pathogenesis of serious diseases, such as neurodegenerative disorders, cancer, liver cirrhosis, cardiovascular diseases, atherosclerosis, cataracts, diabetes and inflammation. Compounds that can scavenge free radicals have great potential in ameliorating these diseases. It is reported that phenolic compounds in plants possess strong antioxidant activity and may help to protect cells against the oxidative damage caused by free radicals. Previous study revealed that mangrove trees, Sonneratia alba Bark showed strong antioxidant activity. Ethyl acetate fraction exhibited the best antioxidant performance. The antioxidant activity of this fraction was attributed to the presence of compounds of different polarities such as phenolics. Furthermore, the phenolic antioxidant of ethyl acetate fraction were purified and identified with UV, IR, MS, and 2D NMR spectrometry. 3,3'-di- $O$-methylellagic acid was found in brown amourphous powder. Antioxidant activity was evaluated and compared with $L-(+)$-ascorbic acid as standard by using DPPH assay. The compound has strong antioxidant activity than ascorbic acid standar with the value of $\mathrm{IC}_{50} 11.35$ and $17.64 \mu \mathrm{g} / \mathrm{mL}$, respectively. The high value of antioxidant activity of compound indicate that $S$. alba is a potential source of natural antioxidant agent.
\end{abstract}

Keywords: DPPH, free radicals, mangrove, phenolics, scavenging activity

\begin{abstract}
ABSTRAK
Radikal bebas berperan penting dalam berbagai penyebab penyakit berbahaya seperti kelainan neurodegeneratif, kanker, penyakit hati, kardiovaskuler, aterosklerosis, katarak, diabetes, dan inflamasi. Senyawa yang dapat menangkap radikal bebas memiliki potensi yang besar untuk mengatasi penyakit-penyakit tersebut. Telah dilaporkan bahwa senyawa fenolik dalam tumbuhan memiliki aktivitas antioksidan yang kuat dan dapat membantu untuk melindungi sel terhadap kerusakan oksidatif yang disebabkan oleh radikal bebas. Studi pendahuluan menunjukkan bahwa tumbuhan mangrove, Sonneratia $a l b a$, kulit batangnya memiliki aktivitas antioksidan yang kuat. Fraksi etil asetat menunjukkan aktivitas antioksidan yang paling kuat. Aktivitas fraksi ini menggambarkan adanya senyawa dengan polaritas yang berbeda seperti fenolik. Dalam penelitian ini diperoleh senyawa antioksidan fenolik dari fraksi etil asetat yang dipurifikasi dan diidentifikasi menggunakan spektrometri UV, IR, MS, dan NMR 2D. Asam 3,3'-di-O-metilellagat diperoleh dalam bentuk serbuk coklat. Aktivitas antioksidan dievaluasi dan dibandingkan dengan asam askorbat $L-(+)$ sebagai standar dengan menggunakan metode DPPH. Senyawa fenolik tersebut memiliki aktivitas antioksidan yang kuat dibandingkan standar asam askorbat dengan nilai $\mathrm{IC}_{50}$ berturut-turut sebesar 11,35 dan 17,64 $\mu \mathrm{g} / \mathrm{mL}$. Aktivitas antioksidan senyawa yang kuat tersebut menunjukkan bahwa S. alba merupakan sumber antioksidan alami yang potensial.
\end{abstract}

Kata Kunci: aktivitas tangkap, DPPH, fenolik, mangrove, radikal bebas

\section{INTRODUCTION}

There is an increasing interest in the role of free radicalmediated damage in the aetiology of human diseases. Free radicals formed during oxidation process occurring in various

*Telp: +6285395972434

Email: urfatama.unm74@gmail.com products and biological systems are known to be responsible for oxidative deterioration, health damage and accelerated aging (Aruoma 2003). Consequently, antioxidants have became an essential part of preservation technology and contemporary health care. Synthetic antioxidants have been widely used in food and medicine. The most commonly used 
synthetic antioxidants are butylated hydroxyanisole (BHA), butylated hydroxytoluene (BHT), and tert-butylated hydroxyquinone (TBHQ) (Lo liger 1991). However, BHA, and BHT were found to be anticarcinogenic as well as carcinogenic in experimental animals. Originally, BHA appeared to have tumor-initiating as well as tumor-promoting action. Recently, it has been established that tumor formation appears to involve only tumor promotion caused by BHA and BHT (Botterweck et al. 2000). The potential toxicity of some synthetic antioxidants, however, has intensified efforts to discover and utilise antioxidants from natural sources (Madsen \& Bertelsen 1995; Nieto et al. 1993; Shahidi \& Wanasundara 1992; Thamavit et al. 1985).

Sonneratia alba, one of mangrove species, has been used as preservative in production of alcoholic traditional beverage from palm trees. It has been reported that $S$. alba bark extract played an important role to prevent the formation of acetate acid generated from oxidation of ethanol (Firdaus \& Sinda 2003). Furthermore, extract of this plant has been used as astringent, antiseptic, and to treat internal bleeding and disentry. We suggest that preservative property of this plant due to the presence of antioxidant or antibacterial compound (Bandarnayake 2002; Kumar et al. 2008). Therefore, this plant might be a good candidate for further development as a nutraceutical or for its antioxidant remedies. However, the potential compound of the bark extracts of $S$. alba as a source of natural antioxidant have not been studied in detail to date. Therefore, it is important to find out the compound that responsible for the extract activity.

The stable radical species 1,1-diphenyl-2-picrylhydrazyl (DPPH), has been widely used for antioxidant capacity screening and estimation due to its clear reaction mechanism, solvent compatibility and the technical simplicity of its assays which requires no special equipment (Chen et al. 1999; Cheng et al. 2006). The purple coloured of DPPH has a strong characteristic absorption at $515 \mathrm{~nm}$ and can undergo reactions with hydrogen donating antioxidant compounds to yield the stable yellow DPPH-H molecule easily monitored with Ultra Violet (UV) spectroscopy (Prior et al. 2005; Roginsky \& Lissi 2005). In this study, several column chromatography (CC) were applied separate and purify the $S$. alba bark extracts; and their antioxidant activities were further evaluated by 1, 1-dipheny1-2-picrylhydrazyl (DPPH) free radical scavenging assay.

\section{MATERIALS AND METHODS}

Materials. All chemical and reagent were analytical grade purchased from Merck (Darmstard-Germany). 1, 1diphenyl-2-picryl hydrazyl (DPPH), L-(+)-ascorbic acid, hexane, chloroform, ethyl acetate, methanol, column Chromatography was carried out on Merck silica gel (200-400 mesh).

Sample preparing was carried out at Organic Chemistry laboratory of Hasanuddin University. The measuring of $1 \mathrm{H}$, 13C, EI-MS, UV, and IR spectra was done at LIPI Serpong Banten. Antioxidant activity was determined at Uji Biofarmaka Laboratory of LPPM IPB Bogor.

Extraction of Bark. Dried and powdered bark of $S$. alba $(10 \mathrm{~kg})$ were extracted with methanol. After filtration, the combined extracts were evaporated to dryness to produce the methanolic extract $(183 \mathrm{~g})$. The methanolic extract was dissolved in a mixture of methanol:water $(2: 3, \mathrm{v} / \mathrm{v})$ at room temperature and partitioned successively with hexane, chloroform and ethyl acetate, produced hexane (23 g), chloroform (49 g) and ethyl acetate (65 g) extracts, respectively. The extracts were concentrated under vacuum. EtAOc showed the highest antioxidant activity, so only this fraction would be continued for further analysis (Figure 1).

The ethyl acetate extract was evaporated in vacuo to give $65 \mathrm{~g}$ residue. The residue was subjected to $(\mathrm{CC})$ on silica gel column, eluted with hexane:ethyl acetate (2:10$5: 10)$ to give five fractions. Antioxidant activity assay showed the $\mathrm{IC}_{50}$ values of those fraction as $\mathrm{E}(15.12 \mathrm{~g} / \mathrm{mL})>$ fraksi D $(15.47 \mathrm{~g} / \mathrm{mL})>$ fraksi C $(16.65 \mathrm{~g} / \mathrm{mL})>$ fraksi $\mathrm{B}$ $(60.88 \mathrm{~g} / \mathrm{mL})>$ fraksi A $(113.95 \mathrm{~g} / \mathrm{mL})$. Fraction C and D were rechromatography on silica gel column eluted with hexane:ethyl acetate $(1: 7-5: 7)$ to give compound 1 (13.25 mg).

DPPH Radical Scavenging Assay. The reaction was performed in $3 \mathrm{~mL}$ of methanol containing freshly prepared 1,1-diphenylpicrylhydrazyl (DPPH) and $1 \mathrm{~mL}$ of fractions/ compounds. Reaction mixtures were protected from light and incubated for $90 \mathrm{~min}$ at room temperature, after which the absorbance of the remaining DPPH was determined colorimetrically at $517 \mathrm{~nm}$. The scavenging activity of compound was measured as the decrease in absorbance of the DPPH expressed as a percentage of the absorbance of a control DPPH solution without compound (Chen et al. 2000). All analyses were carried out in triplicate. 


\section{RESULT AND DISCUSSION}

Isolation and Identifcation of Phenolic Antioxidants from the Bark of $S$. alba. The phenolic antioxidants of EtOAc fraction (Figure 1) were purified and identified by using IR, UV, MS, and 2D NMR spectrometry. Compound 1 was obtained as brown amorphous powder from ethyl acetate, decomposed at $325^{\circ} \mathrm{C}$.

${ }^{1} \mathrm{H}-\mathrm{NMR}$ spectrum shows three proton signal, first signal at $\delta H 10.75 \mathrm{ppm}$ which support the present of hydroxyl group, second signal is at $\delta \mathrm{H} 7.5 \mathrm{ppm}$ identified as protons in the aromatic system and strengthen the structure of the phenolic substituted because it is the only aromatic protons, and the last signal is at $\delta \mathrm{H} 4.0 \mathrm{ppm}$ correspond to the protons on the methoxy group.

MS spectrum shows some peak at m/z 279, 330, 331, dan 305 derived from some fragmentation pattern of acid 3,3 -di-O-metilelagat obtained as the incorporation of molecular compounds or fragments with sodium ions $(\mathrm{Na})$, potassium $(\mathrm{K})$, or molecules of $\mathrm{H}_{2} \mathrm{O}$, and $\mathrm{CH}_{3} \mathrm{OH}$. It is common in molecules with ester or ether groups, the ions are derived from the solvent used.

The results of ${ }^{13} \mathrm{C}-\mathrm{NMR}$ spectrometer $(125 \mathrm{MHz}$, DMSO) analysis shows that there are 8 chemical shifts of carbon atoms in a compound with different environments at $\delta_{\mathrm{C}} 61.0 ; 111.7 ; 141.3 ; 140.3 ; 152.3 ; 111.5 ; 112.2 ;$ and

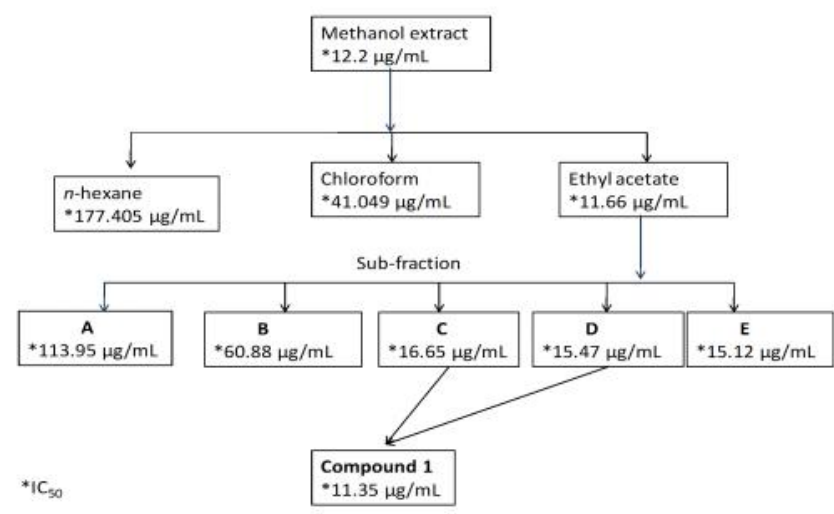

Figure 1 Extraction, fractionation and column chromatography separation of $S$. alba Bark
158.6 ppm (Table 1). Signals with chemical shift $\delta \mathrm{C} 111.5$; 111.7; and $112.2 \mathrm{ppm}$ is double bond carbon signal in aromatic system. Based on those chemical shifts, it determined that the hydroxyl groups attached to the carbon at $\delta \mathrm{C} 152.3 \mathrm{ppm}$, while the methoxy group attached to the carbon with $\delta \mathrm{C} 141.3 \mathrm{ppm}$. The number of aromatic carbon atoms as 6 indicates a benzene unit in the compound. Chemical shift $\delta \mathrm{C} 158.6$ ppm predictable as carbonyl carbon in the cyclic ester or lactone group, where its chemical shift is lower than other types of carbonyl carbon. The data are consistent with the DEPT 135 spectrum showing the presence of the methyl carbon, a carbon metin, and six tertiary carbon. The presence of the unit benzene and lactone groups and fact that the number of carbon atoms only 8 leads to a symmetrical molecule structure.

Data from HMQC spectrum showed that the proton at $\delta H 7.5 \mathrm{ppm}$ attached to the carbon with $\delta \mathrm{C} 111.5 \mathrm{ppm}$, while the protons at $\delta \mathrm{H} 4.0 \mathrm{ppm}$ attached to the carbon with $\delta C 61.0 \mathrm{ppm}$ (Figure 2). HMBC spectrum showed a correlation between the proton at $\delta \mathrm{H} 7.5 \mathrm{ppm}$ with the carbon atom at $\delta \mathrm{C} 112.2,140.3,152.3$, and $158.6 \mathrm{ppm}$. Protons at $\delta \mathrm{H} 4.0 \mathrm{ppm}$ correlated with a carbon atom at $\delta \mathrm{C} 140.3 \mathrm{ppm}$.

Based on the value of the ${ }^{13} \mathrm{C}$-NMR spectra and DEPT 135 , it was determined the position of the carbon atom and hydrogen as follows: $\delta \mathrm{C} 61.0 \mathrm{ppm}(2 \mathrm{x} \mathrm{OCH} 3), 111.6 \mathrm{ppm}(\mathrm{C}-$ 1, C-1 '), 141.2 ppm (C-2, C-2'), 140.2 ppm (C-3, C-3`), 152.2 ppm (C-4, C-4'), 111.4 ppm (C-5, C-5 '), 112.1 ppm (C-6, C $\left.6^{\circ}\right), 158.5 \mathrm{ppm}(2 \mathrm{x} \mathrm{C}=\mathrm{O})$, for the hydrogen atom as follows: $\mathrm{HH} 10.75$ ppm (Ar-OH), 7.5 ppm (H-5, H-5'), and 4, 0 ppm

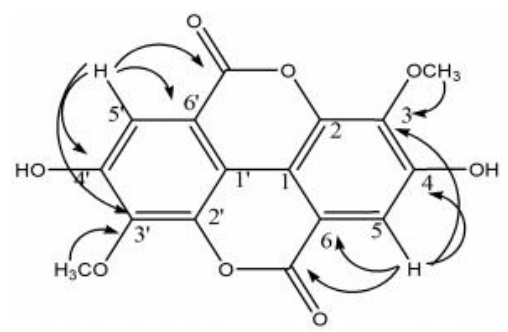

Figure 2 Long distance correlation between proton and carbon atom in 3,3'-di-O-methylellagic acid (HMBC spectra)

\begin{tabular}{ccc} 
Table 1 Data of NMR. ${ }^{1} \mathrm{H}(500 \mathrm{MHz})$ and ${ }^{13} \mathrm{C}(125 \mathrm{MHz})$ obtained compound and reference compound \\
\hline $\begin{array}{c}{ }^{13} \mathrm{C}-\mathrm{NMR} \\
\text { obtained compound }\end{array}$ & $\begin{array}{c}{ }^{13} \mathrm{H}-\mathrm{NMR}-\mathrm{NMR} \\
\text { obtained compound }\end{array}$ & $\begin{array}{c}{ }^{1} \mathrm{H}-\mathrm{NMR} \\
\text { Teference compound (Tian } \text { et al. } 2009)\end{array}$ \\
\hline 111.6 & $7.50(2 \mathrm{H}, \mathrm{s})$, & 11.5 \\
141.2 & & 141.1 \\
140.2 & & 140.2 \\
152.2 & & 111.4 \\
111.4 & & 112.0 \\
112.1 & & 158.4 \\
158.5 & $4.0\left(6 \mathrm{H}, \mathrm{s}, \mathrm{OCH}{ }_{3}\right)$ & 60.9 \\
61.0 & $10.75(\mathrm{OH})$ & \\
\end{tabular}


(2x OCH3). Spectroscopic data analysis was agreed well with the data reported by Tian et al. (2009) (Table 2). Thus, compound 1 was identified as 3,3'-di-O-methylellagic acid (Figure 2).

IR spectrum of compound 1 showed an absorption in the region above $3000 \mathrm{~cm}^{-1}\left(3232 \mathrm{~cm}^{-1}\right)$ derived from unsaturated $\mathrm{CH}$ bond. The presence of absorption at $1612 \mathrm{~cm}^{-1}$ support that $\mathrm{CH}$ is derived from unsaturated aromatic group. Strong absorptions at $1730 \mathrm{~cm}^{-1}$ indicates that the compound contains a carbonyl group $(\mathrm{C}=\mathrm{O})$, and the absorption is specific for lactone (cyclic ester). Broader absorption at $3277 \mathrm{~cm}^{-1}$ indicates that the compound contained an $\mathrm{OH}$ group, this absorption is too low for the range of $\mathrm{NH}$ groups. The presence of the methyl group is characterized by the presence of absorption in the region near $1385 \mathrm{~cm}^{-1}$ and also at $1354 \mathrm{~cm}^{-1}$. The existence of more than one absorption in the region $1000-1300 \mathrm{~cm}^{-1}$ states that there are many type $\mathrm{C}-\mathrm{O}$ bonding. UV spectrum (methanol) shows a maximum absorption at $249 \mathrm{~nm}$ (methanol). This data is consistent with the molecular structure of obtained compounds that indicate the presence of substituted aromatic systems.

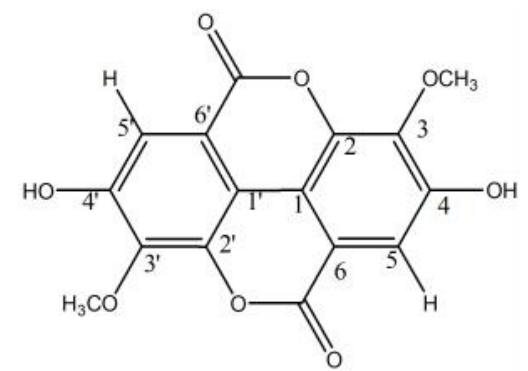

Figure 3 Phenolic compounds isolated from S. alba Bark 3,3'-di-Omethylellagate acid
3,3'-di-O-methylellagic acid is not a new compound. Tian et al. (2009) has reported several compounds from $S$. caseolaries involve 3,3'-di-O-methylellagic acid. It leads that this compound may attributed compound to the family of mangrove trees, Sonneraceae.

$\mathrm{IC}_{50}$ values of extract, fractions, compound from S. alba Bark, and control were determined from linier regression as showen in Tabel 1. 3,3'-di-O-methylellagate acid, and $L-(+)$ ascorbic acid showed concentration dependence-activity until reach the maximum (Figure 3). Maximum activity is reached at concentration $34 \mu \mathrm{g} / \mathrm{mL}$ for 3,3'-di-O - methylellagic acid.

The DPPH assay, which measures the ability of compounds to transfer labile $\mathrm{H}$-atoms to radicals, is the commonest method of antioxidant activity evaluations (Brand-Williams et al. 1995). The abstraction of hydrogen by this stable free radical is known to lead to the bleaching of the maximum absorption $517 \mathrm{~nm}$ and can easily be monitored spectrophotometrically. The synthetic nitrogencentered DPPH radical is not biologically relevant but DPPH assay is often used to evaluate the ability of antioxidant to scavenge free radicals which are known to be a major factor

Table 2 The DPPH scavenging activities of methanolic extracts, fractions and isolated Compound from the Bark of $S$. alba against DPPH free radical

\begin{tabular}{lc}
\hline \multicolumn{1}{c}{ Specimens } & $\mathrm{IC}_{50}(\mu \mathrm{g} / \mathrm{mL})$ \\
\hline Methanol extract & 12.20 \\
$n$-Hexane fraction & 177.05 \\
Chloroform fraction & 41.09 \\
Ethyl acetate fraction & 11.66 \\
3,3 -di- $O$-methylellagate acid & 11.35 \\
$L$-(+)-ascorbic acid & 17.64 \\
\hline
\end{tabular}

All the antioxidant measurements were performed in triplicate,and the data were expressed as average

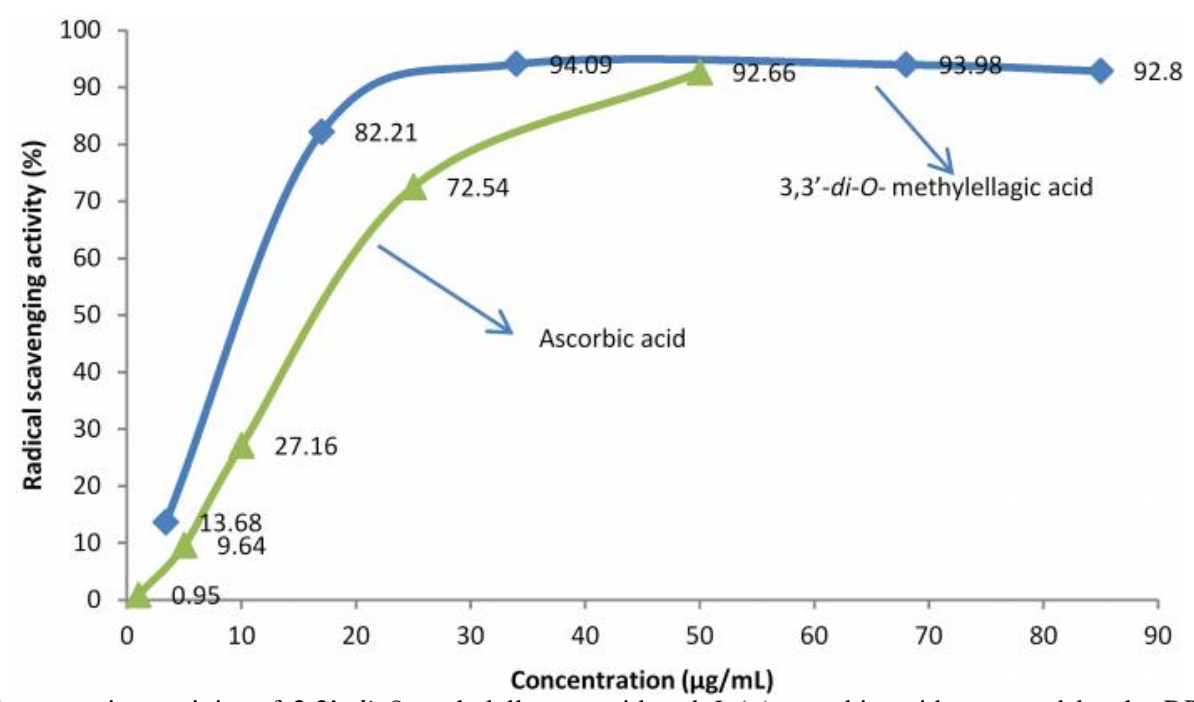

Figure 4 Free-radical scavenging activity of 3,3'-di-O-methylellagate acid and $L$-(+)-ascorbic acid measured by the DPPH 
in biological damages caused by oxidative stress. This assay is known to give reliable information concerning the antioxidant ability of the tested compounds (Huang et al. 2005).

As shown in Table 2, compounds 3, 3'-di-Omethylellagate acid showed significant free radical scavenging activity with $\mathrm{IC}_{50}$ values of $11.35 \mu \mathrm{g} / \mathrm{mL}$ which was much more active than $L-(+)$-ascorbic acid as a positive control. Based on the results obtained from this established assay system, it appears that the compound showed a potent and concentration dependent free radical scavenging effect (Figure 4).

The results in this study reveal that phenolic compounds from $S$. alba Bark showed strong antioxidant. These findings may provide an explanation for some of its uses in folk medicine and preservative property.

\section{CONCLUSION}

The 3,3'-di-O-methylellagate acid is major phenolic antioxidant compound in $S$. alba Bark. It has a very strong antioxidant activity with $\mathrm{IC}_{50}$ value of $11.35 \mu \mathrm{g} / \mathrm{mL}$. The high antioxidant activity of that compound indicate that $S$. alba is potential source of natural antioxidant agent.

\section{ACKNOWLEDGMENT}

Thanks due to the Directorate General of High Education Indonesia for financial supporting, Chemistry Departement of Hasanuddin University for providing the infrastructure, LIPI for measuring spectroscopy spectras, IPB for determining the antioxidant activity. Authors wish to thank Prof. Noor Jalaluddin and Prof. La Daha for best collaboration.

\section{REFERENCE}

Aruoma, O.I. 2003. Methodological considerations for characterizing potential antioxidant actions of bioactive components in plant foods. Mutat Res 253-254: 9-20.

Bandarnayake, W.M. 2002. Bioactivities, bioactive compounds and chemical constituents of mangrove plants. Wetlands Ecol Manage l(10): 421-452.

Botterweck, A.M., Verhagen, H., Goldbohm, R.A., Kleinjans, J \& Brandt, P. A. 2000. Intake of butylated hydroxyanisole and butylated hydroxytoluene and stomach cancer risk: results from analyses in the Netherlands cohort study. Food Chem Toxicol 38: 599-605.

Brandit, P.A.V.D. 2000. Intake of butylated hydroxyanisole and butylated hydroxytoluene and stomach cancer risk: results from analyses in the Netherlands cohort study. Food Chem Toxicol 38: 599-605.
Brand-Williams, W., Cuvelier, M.E \& Benset, C. 1995. Use of free radical method to evaluate antioxidant activity. Lebensm Wiss Technol 28: 25-30.

Chen, Y., Wang, M., Rosen, R.T \& Ho, C-T. 1999. 2, 2Diphenyl-1-picrylhydrazyl radical-scavenging active components from Polygonum multiflorum Thunb. J Agric Food Chem 47: 2226-2228.

Cheng, Z., Moore, J \& Yu, L. 2006. High-throughput relative DPPH radical scavenging capacity assay. J Agric Food Chem 54: 7429-7436.

Chen, C., Tang, H.R., Sutcliffe, L.H \& Belton, P.S. 2000. Green tea polyphenols react with 1,1-diphenylpicrylhydrazyl free radicals in the bilayer of liposomes: direct evidence from electron spin resonance studies. $J$ Agric Food Chem 48: 5710-5714.

Firdaus \& Sinda. L. 2003. Peranan kulit kayu buli Sonneratia $s p$, dalam fermentasi nira aren menjadi minuman beralkohol. Marina Chimica Akta 5(1): 24-28.

Huang, S.T., Chen, C.T., Chieng, K.T., Huang, S.H., Chiang, B.H., Wang, L.F., Kuo, H.S \& Lin, C.M. 2005. Inhibitory effects of a rice hull constituent on tumor necrosis factor a, rostaglandin E2, and cyclooxygenase-2 production in lipopolysaccharide-activated mouse macrophages. Ann N.Y. Acad Sci 1042: 387-395.

Kumar, K.S., Ganesan, P.V \& Subba.R. 2008. Antioxidant potential of solven extracts of Kappaphycus alvarezii (Doty) Doty- An edible seaweed. Food Chem 107: 289295.

Lo liger, J. 1991. The use of antioxidants in foods. In Free radicals and food additives London: Taylor \& Francis.

Madsen, H.L \& Bertelsen, G. 1995. Spice as antioxidants. Trends in Food Sci Technol 6(7): 271-277.

Nieto, S., Garrido, A., Sanhueza, J., Loyola, L.A., Morales, G., Leighton, F., Valenzuela, A. 1993. Flavonoids as stabilizers of fish oil: An alternative to synthetic antioxidants. JAOCS 70: 773-778.

Prior, R.L., Wu, X.L \& Schaich, K. 2005. Standardized methods for the determination of antioxidant capacity and phenolics in foods and dietary supplements. J Agric Food Chem 53: 4290-4302.

Roginsky, V \& Lissi, E.A. 2005. Review of methods to determine chain-breaking antioxidant activity in food. Food Chem 92: 235-254.

Shahidi, F \& Wanasundara, P.K.J.P.D.1992. Phenolic antioxidants. Crit Rev Food Sci 32: 67-103.

Tian, F., Bo, L., Baoping, J., Jinhua, Y., Guizhi, Z., Yang, C \& Yangchao, L. 2009. Antioxidant and antimicrobial activities of consecutive extracts from Galla chinensis: The polarity affects the bioactivities. Food Chem 113: 173-179.

Thamavit, W., Tatematsu, M., Ogiso, T., Mera, Y., Tsuda, B \& Ito, N. 1985. Dosedependant effects of BHA, BHT and ethoxyquin in induction of foci of rat liver cells containing the placental form of glutathione Stransferase. Cancer Lett 27: 295-303. 